\title{
Responding to Change: Lessons from Water Management for Metropolitan Governance
}

\author{
Edward A. Morgan ${ }^{\mathrm{a} *}$, Elnaz Torabi ${ }^{\mathrm{ab}}$, and Ayşın Dedekorkut-Howes ${ }^{\mathrm{ab}}$ \\ ${ }^{a}$ Cities Research Institute, Griffith University, Queensland, Australia; ${ }^{b}$ School of \\ Environment and Science, Griffith University, Queensland, Australia
}

Edward A. Morgan, ed.morgan@griffith.edu.au, ORCID: 0000-0002-9239-4320

Elnaz Torabi ORCID: 0000-0003-4578-8199

Ayşın Dedekorkut-Howes: ORCID 0000-0002-3844-4796

\begin{abstract}
Metropolitan governance is back on the agenda in Australia as cities continue to grow and dominate the economy as well as their surrounding regions. In some sectors, however, metropolitan governance is not new. Water resources have long been governed at a metropolitan scale, even if it has not been explicitly called so. This paper uses the example of water governance in South East Queensland (SEQ) to draw lessons for metropolitan-scale governance across Australia. It discusses why and how water governance in SEQ has become increasingly 'metropolitan', the advantages of this approach, and why it has also proved problematic. In particular, the findings of the research highlight how the approach in SEQ has been fragmented. The paper concludes by outlining recommendations for improving coordination and participation at the metropolitan scale.
\end{abstract}

Keywords: governance; fragmentation; urban water management; drought; catchment management; water supply 


\title{
Responding to Change: Lessons from Water Management for Metropolitan Governance
}

\author{
Metropolitan governance is back on the agenda in Australia as cities continue to grow \\ and dominate the economy as well as their surrounding regions. In some sectors, \\ however, metropolitan governance is not new. Water resources have long been \\ governed at a metropolitan scale, even if it has not been explicitly called so. This paper \\ uses the example of water governance in South East Queensland (SEQ) to draw lessons \\ for metropolitan-scale governance across Australia. It discusses why and how water \\ governance in SEQ has become increasingly 'metropolitan', the advantages of this \\ approach, and why it has also proved problematic. In particular, the findings of the \\ research highlight how the approach in SEQ has been fragmented. The paper concludes \\ by outlining recommendations for improving coordination and participation at the \\ metropolitan scale.
}

Keywords: governance; fragmentation; urban water management; drought; catchment management; water supply

\section{Introduction}

Metropolitan governance emerged in response to the growing urban areas across the world usually maintaining dispersed governance structures consisting of multiple local level administrations (Lefèvre 1998). As a result, political jurisdictions no longer match the patterns of urban material flows and socio-economic demands making planning problems that are best dealt with at a regional scale challenging (Dedekorkut-Howes 2014). Despite moves towards conglomeration most metropolitan areas in industrialised countries, including Australia, consist of numerous local governments (Ahrend, Gamper, and Schumann 2014; Tomlinson 2017; Davidson and Gleeson 2018).

Nevertheless, there has been an increase in governance arrangements that operate at the metropolitan scale across the globe (Heinelt and Kubler 2005; Homsy and Warner 2015; Savitch and Adhikari 2017). At one extreme, in rare instances metropolitan government 
amalgamates the many small local governments into a single large entity covering the metropolitan area (Lefèvre 1998; Tomlinson 2017). More common is the creation of organisations designed to improve coordination of policies across the metropolitan area, termed metropolitan governance or regionalism (Gleeson, Darbas, and Lawson 2004; Ahrend, Gamper, and Schumann 2014; Homsy and Warner 2015; Savitch and Adhikari 2017). These organisations may be focused on a particular sector (e.g. transport or water) or they may be broad-based and operate as another tier of government with varying degrees of statutory power and democratic legitimacy. From a normative perspective, proponents have argued that metropolitan governance provides better outcomes including improving bureaucratic efficiency and creating more economic growth (Ahrend et al. 2014), creating more sustainable cities (Gleeson, Darbas, and Lawson 2004; Davidson and Arman 2014; Homsy and Warner 2015), responding to issues such as climate change (Nguyen, Davidson, and Gleeson 2018), improving planning outcomes (Davidson and Arman 2014; Burton 2017), addressing inequality (Cho, Hong Kim, and Kim 2019), and being more representative and legitimate (OECD 2001; Heinelt and Kubler 2005; Etherington and Jones 2009). For example, in the context of natural resource management, proponents of metropolitan governance argue that individual, smaller municipal governments will find it hard to justify and implement action on transboundary environmental issues such as catchment management because the impacts are felt downstream in another municipality.

In Australia, where there are three tiers of government - Federal, State, and Local -, there has been an increasing focus on regional-scale coordination and cooperation especially around major urban centres (Abbott 2010) and recently calls for metropolitan governance are growing (Gleeson, Darbas, and Lawson 2004; Abbott 2010; Burton 2017; Tomlinson 2017; Steele 2019). At the city scale, with a single large local council Brisbane is often held as an example of metropolitan government. At the regional scale, due to its regional statutory 
planning, the whole South East Queensland (SEQ) region exemplifies metropolitan governance of more than one urban area.

There is little agreement on how to ensure metropolitan governance provides benefits. Studies have shown the productivity benefits of reducing fragmentation (Ahrend et al. 2014), improved outcomes in transport, environment, and sustainability (Homsy and Warner 2015), and limiting sprawl (Gleeson, Darbas, and Lawson 2004; Ahrend, Gamper, and Schumann 2014). However, there are concerns about the legitimacy of metropolitan organisations (Savitch and Adhikari 2017; Jonas and Moisio 2018) as well as their ability to address inequality (Etherington and Jones 2009; Savitch and Adhikari 2017) and improve sustainability and planning (Davidson and Arman 2014; Burton 2017). Some argue that these organisations focus on improving the internal systems by streamlining and rationalising bureaucracy, with little or no focus on outcomes. Others suggest that the pursuit of metropolitan governance is largely driven by and supports a neoliberal globalisation agenda rather than benefiting the cities themselves (Scott 2001; Savitch and Adhikari 2017; Jonas and Moisio 2018). There is still a strong case for metropolitan governance; however, to achieve the expected benefits it is critical to learn from both successes and failures of this approach.

This paper examines the governance of water resources in SEQ focusing on the following research questions: How and why has water governance become more 'metropolitan'? How effective have these changes been? The next section of the paper provides an overview of metropolitan governance focusing particularly on water governance in Australia. After a brief description of the methods and data used in this research, we examine the case study of SEQ through our research questions. We then discuss the implications of our findings for metropolitan governance in general and conclude with lessons learnt and recommendations. 


\section{Australian Urban Water Governance}

Water and its governance are at the heart of resource security and sustainability policy globally (OECD 2015; United Nations 2018). Urban water governance can be defined as "combinations of processes, structures and actors, which provide the architecture to achieve agreement on the values and uses of water, and to coordinate actions to realise these values and uses in water management practice" (Bettini and Head 2013, 6). The literature points to four models of urban water governance: (1) hierarchical, relying on top-down approaches with vertical accountability and poor stakeholder engagement; (2) market, based on greater empowerment of stakeholders and citizens through privatisation, corporatisation, contracts between municipalities and private operators; (3) network, based on decentralised management and cooperation of private, civil, and public actors; and (4) hybrid, which includes significant elements of the others (van de Meene, Brown, and Farrelly 2011; Romano and Akhmouch 2019).

The Australian urban water sector provides drinking water, wastewater, flood mitigation, and stormwater management services to over 20 million Australians (Water Services Association of Australia 2015). This encompasses cities and towns across both metropolitan and regional urban areas (Productivity Commission 2011). Metropolitan regions account for about $73 \%$ of the total Australian water supply system, using over 2.5 million ML (see Figure 1) (Bureau of Meteorology 2018). 


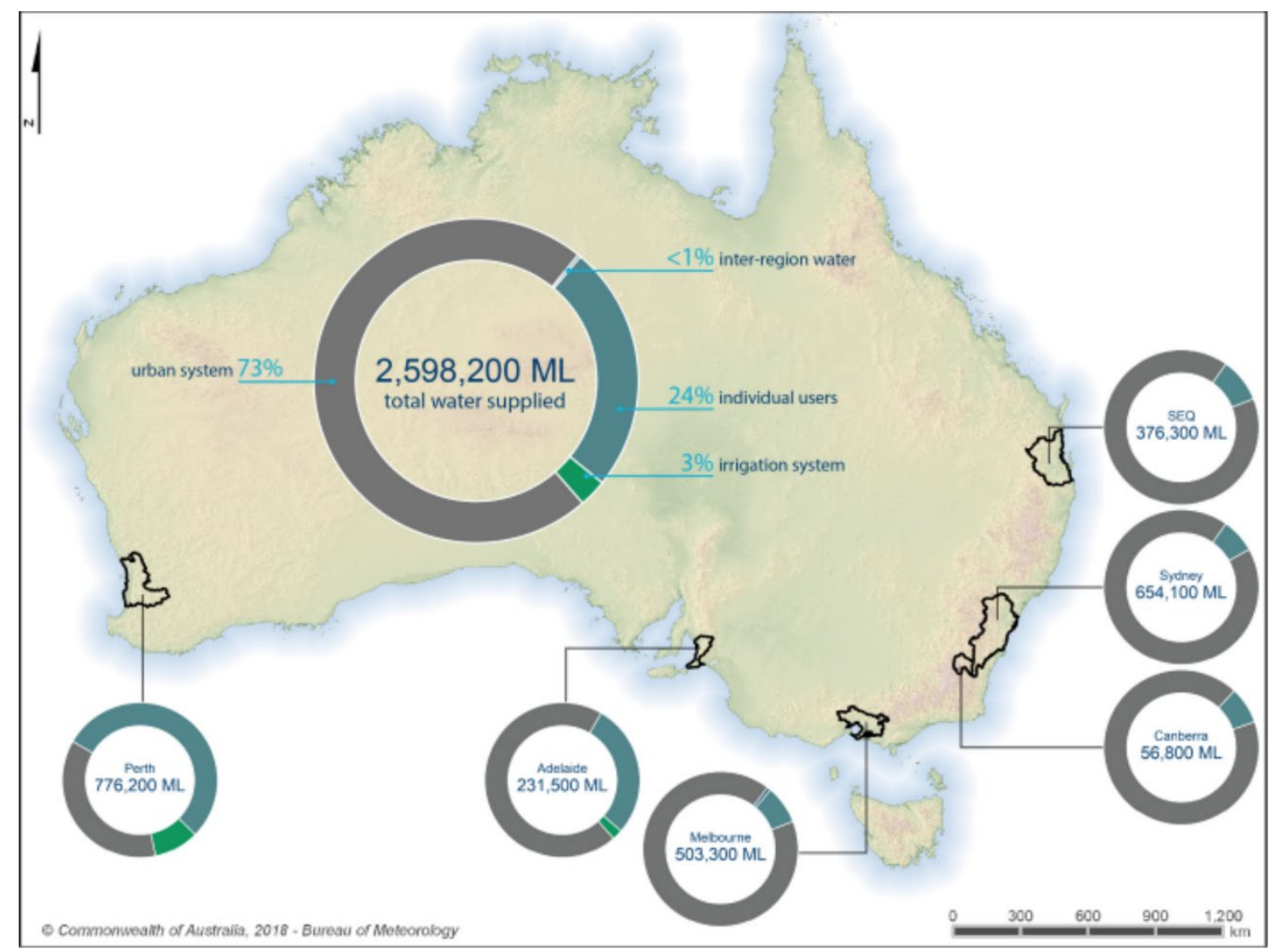

Figure 1: Metropolitan area water usage (Bureau of Meteorology, 2018, used under Creative Commons Licence). Note: individual users are industrial, commercial and agricultural users that do not use the urban potable water supply.

Australian water governance has undergone significant changes in response to growing demand, development, urbanisation, and increasing climate change impacts. Water resources are controlled by the states in Australia, but in response to both the international focus on sustainable development and concerns in the Murray-Darling Basin, the Federal Government began to encourage reforms (Hussey and Dovers 2006, 2007). These reforms were focused on aligning water management with integrated water management as outlined in the Dublin principles and the Our Common Future report (Brundtland et al. 1987).

Prior to the late 1980s, urban water supply in Australia was predominantly managed with an engineering focus by large public works boards responsible for planning, funding, and ownership of infrastructure and services on behalf of state government, while in some regional and metropolitan areas including Brisbane, local councils were also responsible for supply and service functions (Bettini and Head 2013). The micro-economic reforms of the 
1990 s and early 2000s led to major restructuring in the urban water sector with designation of roles and responsibilities to different organisations and state and territory reforms of water service organisations based on corporate business models with greater autonomy (Jane and Dollery 2006; Paddon 2013).

In early 2000s, an extended period of droughts tested the capabilities of the Australian urban water sector and raised several governance and planning challenges for cities (Wallington, Robinson, and Head 2009; Van Dijk et al. 2013), leading to the National Water Initiative which proposed urban water reforms. These reforms were accelerated in 2009 by the adoption of the National Urban Water Planning Principles that focused on a whole of water cycle management in urban areas and consideration of a full portfolio of water supply and demand options (Keremane, McKay, and Wu 2017).

At the same time, building on earlier federal initiatives, Australia developed regionalscale natural resource management, which included catchment management responsibilities based on regional natural resource bodies (Morrison et al. 2010). A series of new urban water reforms are currently under way to meet the needs of a growing population, improve resilience and adaptation to climate change, enhance the capacity of the ageing city infrastructure, reflect the changing community needs, and keep services affordable (Infrastructure Australia 2017).

Urban water management in Australia is a metropolitan governance issue as its provision requires an area-wide scope and its infrastructure has a territorial network character (Kübler 2005). Different dimensions of urban water management include water services (water supply, stormwater management, sewerage, and wastewater management), urban development, and watershed management, responsibilities for which lay with different actors across multiple neighbouring jurisdictions in most metropolitan regions (World Bank 2012). There has been a call for better integration of the urban water sector and engagement of the 
community (van de Meene, Brown, and Farrelly 2009); however, there are still significant institutional barriers to implementation including lack of institutional capacity, fragmentation of roles and responsibilities, lack of political will, and limited regulatory incentives (Brown, Sharp, and Ashley 2006; Keremane, McKay, and Wu 2017). Considering the increasing importance of liveability and the role of water as a vital element of health and wellbeing, there is a need for effective and accountable regional governance mechanisms for better environmental and social impact monitoring and control not only for metropolitan areas, but also regional water catchments (Spiller 2018). The focus on the metropolitan-scale in urban water management has in many ways been ahead of governance shifts to this scale in other sectors. Faced with the Millennium Drought while experiencing one of the fastest population growth rates in the country, SEQ has responded not only with infrastructure investments but also major restructuring of the water sector. We therefore explore a case study of urban water governance in Queensland to draw broader lessons for metropolitan governance.

\section{Methods}

A qualitative research methodology with a case study approach (Yin 2009) incorporates the findings of two projects related to water management in Queensland. The first study included document analysis and 21 semi-structured interviews with key stakeholders that investigated changes to water management in SEQ from 1990 to 2013, focusing on the implementation of the Water Act 2000 in Queensland and the metropolitan response to the Millennium Drought experienced in southern Australia between 1996-2010. The second study focused on climate change adaptation in urban water utility sector. It triangulated data from multiple sources including review of the literature, 20 semi-structured in-depth interviews with water professionals across Australia (Queensland, New South Wales, Australian Capital Territory, Victoria, Western Australia) and a half day workshop with a water utility in Queensland. 


\section{Restructuring of the Water Sector}

Over the last two decades water governance in SEQ has undergone a rapid shift towards a more metropolitan/regional approach which initially resulted in greater centralisation, an increased focus on urban water security, and a fragmentation between water supply and catchment management. Based on the typology mentioned above, urban water supply governance has shifted towards a 'hierarchical-market hybrid' model, while catchment management has moved towards a more 'network' model. Table 1 presents the changes in governance and roles in the urban water sector in SEQ across different aspects of water management. The transition from lower to higher level governance responsibility and scale of operation are highlighted in lighter to darker colour shading. These shifts were driven by international and national policy changes, increasing population and development, and increased demand for water, combined with severe drought conditions lasting nearly a decade. 
Table 1. Urban water governance roles, responsibilities and scales of operation in SEQ ${ }^{\mathrm{a}}$

\begin{tabular}{|c|c|c|c|c|}
\hline $\begin{array}{l}\text { Area of } \\
\text { Operation }\end{array}$ & Pre-reform & $\begin{array}{c}1990-\mathrm{mid} \\
2000 \mathrm{~s}\end{array}$ & $2000 s-2013$ & Post 2013s \\
\hline \multirow[t]{2}{*}{$\begin{array}{l}\text { Bulk Water } \\
\text { Supply }\end{array}$} & $\begin{array}{c}\text { South East } \\
\text { Queensland Water } \\
\text { Board }\end{array}$ & $\begin{array}{c}\text { SEQ Water } \\
\text { Corporation (former } \\
\text { South East } \\
\text { Queensland Water } \\
\text { Board) }\end{array}$ & $\begin{array}{l}\text { Queensland Water } \\
\text { Commission }\end{array}$ & \multirow[t]{2}{*}{ Seqwater } \\
\hline & Local government & Local government & $\begin{array}{c}\text { Seqwater (and } \\
\text { precedents) }^{\mathrm{b}}\end{array}$ & \\
\hline \multirow{2}{*}{$\begin{array}{l}\text { Water Retail } \\
\text { and } \\
\text { Wastewater }\end{array}$} & \multirow{2}{*}{ Local government } & \multirow{2}{*}{ Local government } & $\begin{array}{c}\text { Queensland Urban } \\
\text { Utilities (regional) } \\
\text { Unitywater } \\
\text { (regional) }\end{array}$ & $\begin{array}{l}\text { Queensland Urban } \\
\text { Utilities (regional) } \\
\text { Unitywater } \\
\text { (regional) }\end{array}$ \\
\hline & & & $\begin{array}{l}\text { Allconnex Water } \\
\text { (regional) }\end{array}$ & $\begin{array}{c}\text { Redlands Local } \\
\text { Council, City of } \\
\text { Gold Coast, \& Logan } \\
\text { City Council }\end{array}$ \\
\hline \multirow[t]{2}{*}{$\begin{array}{l}\text { Catchment } \\
\text { Management }\end{array}$} & $\begin{array}{c}\text { Irrigation and Water } \\
\text { Supply Commission } \\
\text { (1979) Department } \\
\text { of Primary Industries } \\
\text { (State) }\end{array}$ & $\begin{array}{c}\text { Queensland Water } \\
\text { Resources } \\
\text { Commission (1992) } \\
\text { Department of } \\
\text { primary industries } \\
\text { (1996) } \\
\text { Department of } \\
\text { Natural resources } \\
(1996-2001)\end{array}$ & $\begin{array}{l}\text { SEQ Catchments } \\
\text { Healthy Waterways } \\
\text { Seqwater }\end{array}$ & $\begin{array}{c}\text { Healthy Land and } \\
\text { Water } \\
\text { Seqwater }\end{array}$ \\
\hline & Local government & Local government & Local government & Local government \\
\hline \multirow{3}{*}{$\begin{array}{l}\text { Flood } \\
\text { Management }\end{array}$} & \multicolumn{4}{|c|}{ State government (policy making at state and regional level) } \\
\hline & \multicolumn{4}{|c|}{ Regional level (e.g. management of dams by Seqwater) } \\
\hline & \multicolumn{4}{|c|}{ Local government through land use and catchments } \\
\hline
\end{tabular}

${ }^{\text {a }}$ Based on Cottingham, Delfau, and Garde 2010; Bettini and Head 2013; Head 2014.

$\mathrm{b}$ The management of alternative water supplies (desalination and recycled water) were transferred from WaterSecure to Seqwater in 2011 and the distribution and management responsibilities of LinkWater and Seqwater Grid Manager were transferred in 2013.

\section{Water Supply and Wastewater Management}

Initial changes to water governance in SEQ responded to the Federal Government's push for water reform. The federal reforms led to the Queensland Water Act 2000, which gave the state ownership of all water resources for the first time, with former riparian rights changed to licences or entitlements (Coffey 2001). The shift to a regional focus took place over the next decade and a half in response to water security concerns.

Prior to the early 2000s the responsibility for bulk water sources, supply, and wastewater treatment rested mainly with local government and a regional Water Board that was commercialised in 2000 as the SEQ Water Corporation (Head 2014). Following the 2000s reforms, urban water management was mostly separated from local governments by 
creation of three regional organisations responsible for bulk water supply across the whole SEQ region: LinkWater, SEQ Water Grid Manager, and WaterSecure.

Water distribution and sales to households and businesses also experienced a regional shift, with three government-owned utility companies - Queensland Urban Utilities (QUU), Unitywater, and Allconnex Water - taking over responsibility of distribution and wastewater management from eleven local governments. These reforms aimed to ensure urban water security and make water governance less political through a more integrated approach which removes local government control over pricing (Troy 2008). The reforms also reflected a wider neoliberal economic shift from government control of services to market-based approaches (Hussey and Dovers 2007); however, they stopped short of full privatisation of water with government ownership of companies.

The droughts highlighted the inadequacies of water resource planning in SEQ from a policy perspective. State government's policy response emerged slowly including a water governance reform with major restructuring and further centralisation of decision-making and water service delivery and the establishment of the Queensland Water Commission to oversee state's water management (Bettini and Head 2013; Head 2014). The South East Queensland Water (Restructuring) and Other Legislation Amendment Act 2012 amalgamated the bulk water entities LinkWater, the SEQ Water Grid Manager, and WaterSecure into Seqwater by 2013 making it responsible for all bulk water storage and treatment across the region. In contrast to centralisation of bulk water, Allconnex Water distribution functions were returned back to Redlands, Gold Coast, and Logan city councils in 2012 due to public pressure that was largely driven by concerns over increased water pricing (Barry and Small 2012). The remaining councils decided to stay with their regional retailers due to the costs of restructuring. At the same time, there was significant infrastructure investment by the state government in response to the Millennium Drought including a new dam, a desalination 
plant, a water recycling facility, and a water grid that connects the region's water supply sources (Troy 2008), which also drove the centralisation of water supply governance.

Ironically, shortly after the drought broke, the region faced severe flooding in 2011 and 2012 leading to debates about the adequacy and sustainability of planning and management of water in the region (Head 2014) with increased focus on the interactions between land use and water management. However, flood management and urban planning and development responsibilities remain mainly at the local government level.

\section{Catchment Management}

Since the early 1950s, land ownership in SEQ was fragmented by small rural landholdings leaving only 17 per cent of the region in state forests and national parks (compared to other Australian cities such as Sydney with 43 per cent), resulting in lower quality of the dam catchment areas (Frost et al. 2016). Prior to 2000s, catchment management was mainly centralised in state government through the establishment of the Queensland Water Resources Commission (replacing the former Irrigation and Water Supply Commission). The catchment scale water resource plans (WRPs) required by the Water Act 2000 shifted catchment management towards a more regional approach (Coffey 2001). Importantly, these WRPs set allocations for extraction and included environmental objectives and the water allocations needed for these - in other words creating statutory environmental allocations.

Although the water reforms in Queensland aimed for a more integrated approach to water management, the land use side of catchment management has largely fallen under a different set of policy changes focused on natural resource management (NRM); however, these also saw a shift to a more regional scale (Cottingham, Delfau, and Garde 2010). Queensland created non-statutory regional NRM bodies based on catchments, with SEQ Catchments created for the SEQ region. At the same time, local councils supported the 
establishment of Healthy Waterways, a regional organisation designed to develop water quality monitoring and address water quality issues through public-private coordination (Cottingham, Delfau, and Garde 2010). Recently, Healthy Waterways was merged with SEQ Catchments to form Healthy Land and Water to improve integration and better drive and influence decisions, policy, and actions.

\section{How Has the Restructuring Worked?}

Despite all the reforms and restructuring towards metropolitan governance interviews with water professionals in the region in 2018 pointed to a lack of integration across the whole water cycle for appropriate management of risks including the impacts of climate change (Torabi et al. 2019). Important findings included the disconnect in the management of wastewater and potable water and lack of effective communication between Seqwater and retailers. One interviewee, a strategic planner in a water utility, discussed the interconnectedness of water in the context of droughts and noted the fragmentation of roles and responsibilities:

As the dams get even lower, we start looking for alternative water sources. Now [bulk water providers] need to find those alternative water sources, but usually they are reliant on the effluent from our treatment plants or recycling the wastewater that we collect. So, all of a sudden, it is difficult to understand the delineation [of] responsibilities between water supply and wastewater management.

A critical challenge is managing the interactions between stormwater flooding and water quality risks that arise due to wastewater overflow during flooding, issues that are closely related but governed by separate organisations (councils versus utilities). A drought project manager suggested, "We as a collective sector need to be able to understand how we address it together [...] Otherwise one organisation bears more of the risk." Ironically, the shift of water management responsibilities from local governments to regional retailers has 
resulted in a fragmentation of planning particularly from a land use point of view. A planner for the region's bulk water supply noted:

We are managing elements of catchments. With local governments making decisions about catchment land use, at the moment we just have the ability to provide advice on, we don't have a strong ability to control that $[\ldots]$ so we have got these fragmented pieces of the water cycle that are being managed separately.

A senior planner at a regional utility agreed: "We have a role to play with the use of recycled water, use of potable water in green spaces, but we do not control the urban planning. We influence it." The interviewees also referred to a lack of collaboration between regional water utilities and neighbouring local governments that is essential for a whole of catchment approach to urban water management.

This lack of integration, while enabling a rapid response to the immediate drought, makes more strategic long-term planning challenging. Responding to the many impacts of climate change, for example, requires an integrated approach to planning (Holden 2012). A regional drought manager referred to some collaboration in the context of disaster management, but noted that

all of the local governments, which are shareholders, are grappling with these same problems. They have responsibilities under Disaster Management Act. So that level of collaboration needs to be happening better, it has improved, but there is still a long way to go.

A water sector industry body manager concurred: "The [water] industry is very good at talking amongst themselves and we are a very collaborative industry, but what is happening overseas that is not happening well here [is] industries working together towards common value." A regional utility manager concluded that "a lot of this, we can't do on our own so we are going to have to partner and those partners could be our shareholders, regulators, or our communities". 


\section{Discussion}

The case of urban water management in SEQ points to fragmentation and lack of integration of roles and responsibilities and centralisation of response as the key challenges pertinent to metropolitan governance. As noted above, water supply and catchment management fell into very separate governance arrangements, both operating at similar scales but with quite different aims. Prior to this, catchment management and water supply were both very focused at the local level, in theory allowing for integration (although this was by no means guaranteed). Later restructuring of the water sector at the SEQ metropolitan level, and particularly the commercialisation of utilities that are responsible for distribution of drinking water (from Seqwater) to households and businesses and management of wastewater, led to further fragmentation of roles and responsibilities.

This separation of governance, combined with centralisation of water supply management, was in part due to a need for a rapid and coordinated response to a severe drought. However, it has also encouraged water supply management to focus heavily on urban water security. This in turn led to a strong focus on technocratic, engineering responses to the drought and investment in substantial infrastructure such as the Water Grid, which is reliant on power stations across the region that ironically are using potable water for cooling processes (Frost et al. 2016). Moreover, the monopoly of organisations on management of different parts of the urban water/wastewater cycle (i.e. Seqwater and the utilities) means that despite the recognition of the need for better collaboration, lack of additional resources and current financial directives for investment (to be prudent and efficient) do not allow enough flexibility for each organisation to be considering issues beyond its own immediate responsibilities. The commercialisation of utilities led to a narrowing down of their operations to core business activities, which in most cases prevented them from engaging in broader emerging strategic issues such as integrated water management (Bettini and Head 
2013). The engineering focus remains, and the lack of integration renders alternative responses (or anything outside business as usual) challenging or impossible. Having bulk water supply controlled by one organisation with a clear focus on ensuring adequate supply requires making a strong business case and changing the overall aim of the organisation to make metropolitan-scale catchment management to be part of the business.

Effective and timely engagement of communities in urban water management is an important issue that can be difficult to implement in a centralised and fragmented supply chain. The demand control response to droughts has been highly effective in SEQ (Walton and Hume 2011) demonstrating the possibilities of community engagement. However, this was largely achieved despite metropolitan centralisation and market-based reforms rather than because of them, with delivery focused at a local government scale (England 2009). Notably, in issues around building dams and water recycling, community engagement was often limited (in part due to the urgency of the issue) and resulted in confrontation (Morgan and Grant-Smith 2015; Morgan and Osborne 2016). Community engagement in urban water management can improve water planning outcomes, build trust in organisations, and help achieve water sensitive outcomes for urban resilience and sustainability (Dean et al. 2016; Hatfield-Dodds, Leitch, and Syme 2007). Furthermore, while the shift to metropolitan organisations makes them less political, potentially supporting a longer-term response and more strategic planning (Troy 2008), it can result in organisations being less directly politically accountable (Morgan 2014).

There is evidence of water governance in the region becoming more integrated and the metropolitan scale arrangements have the potential to support this integration. For example, catchment management is becoming an increasing focus for bulk water supplier Seqwater, and the links between catchment management, water quality, and water treatment costs are providing an opportunity to broaden the business focus and collaboration. What is 
critical in this debate is the timely and meaningful engagement of the local communities. QUU's 'effects-based planning' initiative which achieves better environmental outcomes in wastewater and stormwater management in a unique collaboration with the local community by promoting blue/green infrastructure is a good example (QUU 2016).

Metropolitan urban water management in SEQ is also creating opportunities for future planning and realisation of broader sustainability outcomes in the region. In 2018, Seqwater partnered with a private consultancy and all other service providers in the region to collaboratively develop scenarios for the future of the region. By bringing the key regional stakeholders together, the program uncovered crucial learnings in planning for an uncertain future. A key underpinning of this process is creation of shared goals and 'values' that can drive collaboration among different stakeholders and local communities. A metropolitan approach to governance in SEQ can be an important opportunity for promoting liveability in the cities. While urban development and urban water are often managed in their own silos, metropolitan governance can be an important catalyst for liveability of cities. For example, the South East Queensland Regional Plan 2017 Shaping SEQ promotes a water sensitive region to enable an integrated approach to 'whole of catchment planning' in order to accommodate urban and peri-urban growth in a changing climate and promote liveability.

\section{Conclusions}

Overview of the governance reforms in the water sector in SEQ and insights from practitioners show that while a shift to metropolitan scale of governance did initially limit holistic and integrated water management by creating a fragmented approach to water supply, catchment management, and wastewater management, it later created opportunities for better integration and collaboration. 
The current water governance structure in SEQ has weaknesses and strengths. Concentrating the bulk water supply in a single entity (Seqwater) allows long-term and expensive investment decisions to be made with a regional focus. There are numerous cases of parochial interests hampering a regional vision in fragmented management structures (see for example Dedekorkut-Howes [2005] for the Tampa Bay, Florida case). However, the integration is unfortunately limited to the single issue of bulk water supply. The disassociation of the bulk water entity from catchment management and land use hinders a more effective management and sustainable outcomes. On the retail side, the two competing models (see Table 1) also have their advantages and disadvantages. The regional retail entities QUU and Unitywater ensure a consistency in level of service and water pricing but they are also separated from catchment management and land use. The three councils that undertake their own retail service have the advantage of also controlling land use and catchment management but are in danger of neglecting regional and collective interests. Furthermore, land use and water policies are handled by separate departments of each council and coordination between these departments is also limited.

SEQ is on the verge of another period of drought. Therefore, realisation of the opportunities of metropolitan governance is critical. Yet on the ground implementation and collaboration can be constrained by many organisational factors. In particular, whether metropolitan governance will help or hinder community engagement remains to be seen.

The history of water management in SEQ provides several lessons for metropolitan governance in general. Metropolitan governance needs to be implemented with clear aims in mind and with consideration of the context. Another key lesson is the need to think holistically both in terms of area of governance as well as policy areas and issues for more efficient and sustainable outcomes. In the absence of regional organisations in charge of the whole geographic area as well as relevant policy areas interorganisational coordination and 
collaboration are essential. A network of key organisations with shared values is crucial to support integration over time. This should also be underpinned by timely and meaningful community engagement. Planners play an important role in driving a more integrated approach to planning, bringing together land use and key infrastructure considerations.

Institutional structures are important as they can facilitate or hinder this holistic thinking; however, metropolitan governance is not a panacea, and if it is not done with the specific goal of sustainability and integration it may not deliver the positive outcomes so often claimed. Nonetheless, from a more pragmatic point of view a focus on the metropolitan scale could be a good stepping-stone towards more holistic governance of natural resources and sustainable outcomes.

Acknowledgements: We would like to thank the anonymous reviewers whose constructive feedback improved our paper. 


\section{References}

Abbott, J. 2010. "Regions of Cities: Metropolitan Governance and Planning in Australia." In Governance and Planning of Mega-City Regions: An International Comparative Perspective, edited by Jiang Xu and Anthony G. O. Yey, 172-190. London: Routledge.

Ahrend, R., C. Gamper, and A. Schumann. 2014. "The OECD Metropolitan Governance Survey: A Quantitative Description of Governance Structures in Large Urban Agglomerations." In OECD Regional Development Working Papers. Paris: OECD.

Barry, S., and S. Small. 2012. "Parliament Dissolves Water Retailer Allconnex." $A B C$, February 2012. https://www.abc.net.au/news/2012-02-15/parliament-dissolveswater-retailer-allconnex/3830632.

Bettini, Y., and B. Head. 2013. "Specifying the Urban Water Governance Challenge: Better Governance for Complex Decision-Making." Clayton, Melbourne, Victoria: Cooperative Research Centre for Water Sensitive Cities.

Brown, R. R., L. Sharp, and R. M. Ashley. 2006. "Implementation Impediments to Institutionalising the Practice of Sustainable Urban Water Management." Water Science and Technology 54 (6-7): 415-422. doi: 10.2166/wst.2006.585.

Brundtland, G.H., M. Khalid, S. Agnelli, S. Al-Athel, and B. Chidzero. 1987. Our Common Future. New York: Oxford University Press.

Bureau of Meteorology. "National Water Account 2018: Urban Regions." Bureau of Meteorology, Accessed 07 January 2020 http://www.bom.gov.au/water/nwa/2018/urban/index.shtml.

Burton, P. 2017. "Is Urban Planning in Australia Hindered by Poor Metropolitan Governance?" Urban Science 1 (4): 34. doi: 10.3390/urbansci1040034.

Cho, J., J. H. Kim, and Y. Kim. 2019. "Metropolitan Governance Structure and GrowthInequality Dynamics in the United States." Environment and Planning A: Economy and Space 51 (3): 598-616. doi: 10.1177/0308518X18810002.

Coffey, F. C. 2001. "Assessment of Water Resource Plans under the Water Act 2000 (Qld) With Consideration of Ecological Outcomes and Environmental Flow Objectives in the." Environmental and Planning Law Journal 18: 410-437.

Cottingham, R., K. F. Delfau, and P. Garde. 2010. "Managing Diffuse Water Pollution in South East Queensland: An Analysis of the Role of the Healthy Waterways Partnership." Brisbane: International Water Centre.

Davidson, K., and M. Arman. 2014. "Planning for Sustainability: An Assessment of Recent Metropolitan Planning Strategies and Urban Policy in Australia." Australian Planner 51 (4): 296-306. doi: 10.1080/07293682.2013.877508.

Davidson, K., and B. Gleeson. 2018. "New Socio-ecological Imperatives for Cities: Possibilities and Dilemmas for Australian Metropolitan Governance." Urban Policy and Research 36 (2): 230-241. doi: 10.1080/08111146.2017.1354848.

Dean, A., K. Fielding, F. Newton, and H. Ross. 2016. "Community Engagement in the Water Sector: An Outcome-Focused Review of Different Engagement Approaches." Clayton, Vicoria: Cooperative Research Centre for Water Sensitive Cities.

Dedekorkut, A. 2005. “Tampa Bay Water Wars: From Conflict to Collaboration?” In Adaptive Governance and Water Conflict: New Institutions for Collaborative Planning, edited by John T. Scholz and Buce Stiftel, 52-63. Washington, D.C.: Resources for the Future. 
Dedekorkut-Howes, A. 2014. "Bioregional Planning and Growth Management." In Australian Environmental Planning: Challenges and Future Prospects, edited by Jason Byrne, Jago Dodson and Neil Sipe, 234-245. London: Routledge.

England, P. 2009. "Managing Urban Water in Australia: The Planned and the Unplanned." Management of Environmental Quality: An International Journal 20: 592-608. doi: 10.1108/14777830910981258.

Etherington, D., and M. Jones. 2009. "City-Regions: New Geographies of Uneven Development and Inequality." Regional Studies 43 (02): 247-265. doi: 10.1080/00343400801968353.

Frost, L., A. Gaynor, J. Gregory, R. Morgan, S. O’Hanlon, P. Spearritt, and J. Young. 2016. "Water, History and the Australian City: Urbanism, Suburbanism and Watering a Dry Continent, 1788-2015." Clayton, Victoria: Cooperative Research Centre for Water Sensitive Cities.

Gleeson, B., T. Darbas, and S. Lawson. 2004. "Governance, Sustainability and Recent Australian Metropolitan Strategies: A Socio-theoretic Analysis." Urban Policy and Research 22 (4): 345-366. doi: 10.1080/0811114042000296290.

Hatfield-Dodds, S., A. Leitch, and G. Syme. 2007. "Improving Australian Water Management: The Contribution of Social Values Research and Community Engagement [online]." Reform 89: 44-48.

Head, B. W. 2014. "Managing Urban Water Crises: Adaptive Policy Responses to Drought and Flood in Southeast Queensland, Australia." Ecology and Society 19 (2): 33. doi: 10.5751/ES-06414-190233.

Heinelt, H. , and D. Kubler. 2005. Metropolitan Governance: Capacity, Democracy and the Dynamics of Place. New York: Routledge.

Holden, M. 2012. "Is Integrated Planning Any More Than the Sum of Its Parts?: Considerations for Planning Sustainable Cities." Journal of Planning Education and Research 32 (3): 305-318. doi: 10.1177/0739456x12449483.

Homsy, G. C., and M. E. Warner. 2015. "Cities and Sustainability: Polycentric Action and Multilevel Governance." Urban Affairs Review 51 (1): 46-73. doi: $10.1177 / 1078087414530545$.

Hussey, K., and S. Dovers. 2007. "Managing Water for Australia: The Social and Institutional Challenges." Collingwood, Vic: CSIRO Publishing.

Hussey, K., and S. Dovers. 2006. "Trajectories in Australian Water Policy." Journal of Contemporary Water Research \& Education 1 (135): 36-50.

Infrastructure Australia. 2017. "Reforming Urban Water." Sydney, Australia: Infrastructure Australia.

Jane, A., and B. Dollery. 2006. "Public Sector Reform in Australia: An Evaluation of the Corporatisation of Sydney Water, 1995 to 2002." Australian Journal of Public Administration 65 (4): 54-67. doi: 10.1111/j.1467-8500.2006.00504a.x.

Jonas, A. E.G., and S. Moisio. 2018. "City Regionalism as Geopolitical Processes: A New Framework for Analysis." Progress in Human Geography 42 (3): 350-370. doi: $10.1177 / 0309132516679897$.

Keremane, G., J. McKay, and Z. Wu. 2017. "Urban Water Governance for the TwentyFirst Century: A Portfolio-Based Approach to Planning and Management." In Freshwater Governance for the $21^{\text {st }}$ Century, edited by Eiman Karar, 103-127. Cham: Springer International Publishing.

Kübler, D. 2005. "Problems and Prospects of Metropolitan Governance in Sydney: Towards 'Old' or 'New' Regionalism?” Kensington, NSW: City Futures Research Centre, University of New South Wales. 
Lefèvre, C. 1998. "Metropolitan Government and Governance in Western Countries: A Critical Review." International Journal of Urban and Regional Research 22 (1): 925. doi: 10.1111/1468-2427.00120.

Morgan, E. A. 2014. "Science \& Sustainability: The Use of Science and the SciencePolicy Interface in Sustainable Water Resource Management." PhD diss., Griffith University.

Morgan, E. A., and D. C. C. Grant-Smith. 2015. "Tales of Science and Defiance: The Case for Co-learning and Collaboration in Bridging the Science/Emotion Divide in Water Recycling Debates." Journal of Environmental Planning and Management 58: 1770-1788. doi: 10.1080/09640568.2014.954691.

Morgan, E. A., and N. Osborne. 2016. "It's the Lungfish, Stupid: Knowledge Fights, Activism, and the Science-Policy Interface." Geographical Research 54: 365-376. doi: 10.1111/1745-5871.12181.

Morrison, T. H., C. McAlpine, J. R. Rhodes, A. Peterson, and P. Schmidt. 2010. "Back to the Future? Planning for Environmental Outcomes and the New Caring for Our Country Program." Australian Geographer 41: 521-538. doi: 10.1080/00049182.2010.519763.

Nguyen, T. M. P., K. Davidson, and B. Gleeson. 2018. "Metropolitan Strategies and Climate Governance: Towards New Evaluative Approaches.” International Journal of Urban and Regional Research 42 (5): 934-951. doi: 10.1111/1468-2427.12662.

OECD. 2001. Cities for Citizens: Improving Metropolitan Governance. Paris: OECD Publishing.

Paddon, M. 2013. "Urban Water Governance in Australia: The Private Sector at the Margins." In Water Governance: An Evaluation of Alternative Architectures, edited by A. Gunawansa and L. Bhullar. Cheltenham, UK: Edward Elgar Publishing.

Productivity Commission. 2011. “Australia's Urban Water Sector, Productivity Commission Inquiry Report, Volume 1." Canberra: Commonwealth of Australia.

Queensland Urban Utilities. 2016. "Urban Water Pollution, A Water Utility Perspective." Presented at the Brisbane Catchments Network, Brisbane, February 2016.

Romano, O., and A. Akhmouch. 2019. "Water Governance in Cities: Current Trends and Future Challenges." Water 11 (3): 500. doi: 10.3390/w11030500.

Savitch, H. V., and Sarin Adhikari. 2017. "Fragmented Regionalism: Why Metropolitan America Continues to Splinter." Urban Affairs Review 53 (2): 381-402. doi: $10.1177 / 1078087416630626$.

Scott, A. J. 2001. "Globalization and the Rise of City-regions." European Planning Studies 9 (7): 813-826. doi: 10.1080/09654310120079788.

Steele, W. 2019. "Metropolitan Governance: The Victorian Challenge (or Opportunity?)." Planning News 45 (3): 12.

Tomlinson, R. 2017. "An Argument for Metropolitan Government in Australia." Cities 63: 149-153. doi: 10.1016/j.cities.2016.10.013.

Torabi, E., A. Dedekorkut-Howes, M. Howes, and J. Byrne. 2019. "Barriers and Drivers to Australian Water Utilities' Adaptation to Climate Change." State of Australian Cities 2019 Conference Proceedings.

Troy, P.. 2008. Troubled Waters. Confronting the Water Crisis in Australia's Cities. Canberra: ANU Press.

United Nations. 2018. "Sustainable Development Goal 6, Synthesis Report 2018 on Water and Sanitation." New York, USA: United Nations Publications.

van de Meene, S. J., R. R. Brown, and M. A. Farrelly. 2009. "Exploring Sustainable Urban Water Governance: A Case Study of Institutional Capacity." Water Science and Technology 59 (10): 1921-1928. doi: https://doi.org/10.2166/wst.2009.190. 
van de Meene, S. J., R. R. Brown, and M. A. Farrelly. 2011. "Towards Understanding Governance for Sustainable Urban Water Management." Global Environmental Change 21 (3): 1117-1127. doi: https://doi.org/10.1016/j.gloenvcha.2011.04.003.

Walton, A., and M. Hume. 2011. "Creating Positive Habits in Water Conservation: The Case of the Queensland Water Commission and the Target 140 Campaign." Journal of Nonprofit and Voluntary Sector 16 (3): 215-224. doi: 10.1002/nvsm.421.

Water Services Association of Australia. 2015. "Doing the Important, As Well As the Urgent: Reforming the Urban Water Sector.” Sydney: Infrastructure Partnerships Australia and Water Serices Association of Australia.

World Bank. 2012. "Integrated Urban Water Management: A Summary Note." Washington, DC: The World Bank.

Yin, R.K. 2009. Case Study Research: Design and Methods, $4^{\text {th }}$ Edition. London, UK: Sage Publications. 